\title{
ARTHRITIS AND RHEUMATISM COUNCIL
}

\author{
FOR RESEARCH IN GREAT BRITAIN AND THE COMMONWEALTH
}

\author{
TWENTY-SEVENTH ANNUAL REPORT*
}

The 27th Annual Report was presented by the Chairman, the Rt. Hon. the Viscount Knollys, at the Annual General Meeting held at the Guildhall, City of London, on May 7, 1964.

The Chairman expressed the Council's pleasure at the election of Dr. W. S. C. Copeman as President and also drew attention to the Council's new name, designed to emphasize the connexion between arthritis and rheumatism, and to stress the Council's work of research. It had been decided to expand the lay element of the Council and Lord Wakefield had consented to become Chairman of the Appeals Committee.

Dr. Oswald Savage, the hon. medical secretary, described the research projects sponsored by the Council, and explained some of the advances made in the past year, particularly in biochemical and serological studies and in large epidemiological surveys.

The report includes a synopsis of the Council's work written for the layman, covering five fields of study and ranging across the world to the Americas and the Antipodes. New buildings and equipment have been made available by many hospital authorities, and gifts and bequests have enabled the programme of research to be much extended. The principal grant for research is one of $£ 200,000$ over the next 10 years to the Kennedy Institute now established at the Charing Cross Hospital. There are five other research units in operation and grants have been made to three hospital research centres and to 32 individual research projects. Equipment has been provided at six hospitals and medical schools and the two professorial chairs of rheumatology are being maintained at the Universities of London and Manchester.

* Full details of the activities of the Council for the year 1962-63 are given in the Report, which may be obtained from the Secretary, Mr. M. C. G. Andrews, Faraday House, 8 Charing Cross Road, London, w.C.2.

\section{RESEARCH}

Mobile Field Survey Unit based on the University of Manchester (Director: Dr. J. S. Lawrence, M.R.C.P.).Since the completion of the field work on the Jamaican survey in November, 1962, the Unit has been employed in preparing for analysis the material gathered in the past few years. The biochemical and serological tests in the Watford survey, the Manchester family study, and the Jamaican survey, and the first reading of the $x$ rays taken in Manchester study are nearly complete.

It is hoped soon to begin reading the $x$ rays taken in Jamaica, which are to be compared with those taken during surveys by other Units among American Indians in Arizona, Montana, and British Columbia, using the $x$ rays taken in Wensleydale as controls.

Foundry Survey.-The material obtained by the foundry workers survey has been analysed. It shows a lower level of rheumatic complaints among the foundry workers (63 per cent.) than among the control population drawn from the Leigh surveys (73 per cent.), with a corresponding reduced level of prolonged loss of work (9 per cent. compared with 14 per cent.). Complaints were mainly of pain in the back and groins, and there were many fewer complaints of pain in the thighs, knees and feet than in the control population.

Radiological evidence of lumbar disk degeneration was significantly more common among the foundry workers (18 per cent.) than among the controls (11 per cent.) in all age groups.

It is postulated that the warm dry atmosphere of the foundry acts in a similar manner to physiotherapy, helping to reduce the number of complaints among the workers.

Watford Survey.-Preliminary analysis of this survey shows that clinical rheumatoid arthritis was found in 2 per cent. of males and 3 per cent. of females, none of whom had severe disease. Radiological evidence of erosive arthritis, taking all sites, was found in 11 per cent. of both sexes but, except in two, was of minimal severity. A positive sheep cell agglutination test (SCAT) was found in 0.6 per cent. of males and in 1.7 per cent. of females (a significantly lower figure than the expected rate derived from the Leigh-Wensleydale random samples). 
Manchester Family Study.-In collaboration with the staffs of the Rheumatism Research Centres in Manchester and Taplow, a start has been made on the analysis of the material relevant to systemic lupus erythematosus obtained by this survey.

Jamaica Survey.-A preliminary analysis of the clinical material has shown that a diagnosis of inflammatory polyarthritis was made in 5 per cent. of males and 9 per cent. females. The disease was mild in most cases, and no persons with severe arthritis (grade 4) were found in the random sample, though several severe classical cases were seen in a review of forty patients who had attended University College Hospital, West Indies.

Sera obtained from the persons seen in the survey have been investigated by Dr. J. Ball. The sheep cell agglutination test (SCAT) was positive at a titre of 1 in 32 or higher in 2.4 per cent. of males and 0.8 per cent. of females, a frequency significantly lower than that expected.

These figures show that, though inflammatory polyarthritis is usually mild in this population, it is not less frequent than in temperate climates.

Serology.-In association with Drs. W. Hijmans and H. Valkenburg of the Leyden University Hospital, Holland, further investigations are being made into the relationships between the SCAT, Bentonite (BFT), and Latex (LFT) serum factors, using the sera obtained in the Wensleydale survey.

The preliminary results show some highly interesting inter-relationships and it is hoped that further study on larger numbers may help to elucidate the significance of the presence of these factors in sera and their relationship to rheumatoid arthritis.

Standards.-One of the most important uses of the materials of the Leigh and Wensleydale surveys and the data derived from them has been to provide standards or controls for a wide variety of research projects. Such use has already been made of clinical data in studies on spondylitis in British Columbia, in a New York family study, and in a study on polycythaemia. Both the $x$ rays and the serological data are also frequently used as controls and the Field Unit is serving a useful purpose as a library of $x$ rays from random population samples.

Industrial Survey Unit based on Edinburgh University (Director: Dr. J. J. R. Duthie, F.R.C.P.E.).-This Unit, which has now completed its third year, was formed to study the social and economic effects of rheumatic diseases in industry, and is accommodated in the Northern General Hospital, Edinburgh.

A survey conducted in an electronic engineering works in Edinburgh provided an opportunity to compare the prevalence of rheumatic complaints in light industry with that prevailing in the heavier industries already studied. It also permitted a comparison between men and women performing similar work under identical conditions.

The findings confirm the impression that sickness absence due to rheumatism is lower in lighter and more sedentary work than in the heavier and more strenuous occupations, even though the prevalence of rheumatic complaints is similar.

The follow-up study of the male sample in Rosyth Dockyard is being continued for another year to observe changes in sickness absence and changes of occupation that may occur through ill-health.

At present a further group of foundry workers is being studied to increase the number already seen in a pilot survey.

Future plans include a survey of agricultural workers in a nearby rural community.

With the co-operation of the College of General Practitioners it is hoped to make a closer assessment of the social and economic effects of rheumatism in the general population and of the use made of medical services by patients with rheumatism. This study will provide access to a section of the population which would not otherwise be seen in industry.

Scottish Research Unit.-(Director: Dr. J. J. R. Duthie, F.R.C.P.E.).

The Macfarlane Wing at the Northern General Hospital, Edinburgh, named after Mr. Robert and Mr. John Macfarlane, whose generosity made the building possible, was officially opened by the Lord Provost of Edinburgh on October 30,1963. The orthopaedic workshop is now almost fully equiped and is already providing an excellent service to both physicians and orthopaedic surgeons, in the provision of splints tailored to meet the needs of individual patients. Mr. J. Hepburn, the orthopaedic technician, is showing considerable ingenuity in the design of appliances, and it is hoped to initiate clinical trials in the near future.

Unit on Drug Action.-King's College Hospital Medical School, London (Director: Dr. M. J. H. Smith, M.Pharm., Ph.D., F.R.I.C.).-The principal aim of the initial phase of the research team has been to discover, and to define as closely as possible in biochemical terms, any major effects of anti-rheumatic drugs on cellular metabolism. During the last 2 years the main emphasis has been on the action of salicylates. This involves research on important groups of tissue enzymes, particularly the transaminases and the dehydrogenases.

Through the generosity of Messrs. Smith and Nephew Associates Ltd., to whom the Council is very grateful, a new Fellowship has been established in the Unit.

Electron Microscopy Unit.-St. Thomas' Hospital Medical School, London (Director: Professor D. V. Davies, D.Sc., M.A., M.B., B.S., F.R.C.S.).

The work of this unit during the year has included:

(a) Co-operation with the M.R.C. Rheumatism Unit at Taplow.

(b) Examination of tissue from Dr. Currey at the London Hospital.

(c) Study of changes in ageing articular cartilage by Drs. Barnett, Palfrey, and Cochrane.

(d) Study of absorption by articular cartilage and synovial membrane. 
This work is yielding interesting information on the permeability of cartilage and on the mechanism of absorption by the synovial membrane.

Other Research Units.-The Council has also given financial support to rheumatism research units in the following hospitals:

The London Hospital (Dr. W. S. Tegner, F.R.C.P.).

Chelsea and Kensington Group Rheumatism Unit (Dr. A. St.J. Dixon, M.R.C.P.).

Westminster Hospital, London (Dr. F. Dudley Hart, F.R.C.P.).

\section{Other Research Projects}

(1) Chemical and Physical Properties of Collagen.Large funds have been applied to investigations into the fundamental properties of collagen.

Mr. F. R. Partington, who is working under Prof. J. H. Kellgren in the Rheumatism Research Department at Manchester University, has been studying the physical properties of tendon fibres.

In New Zealand, at the University of Otago, Dr. T. Highton is studying the effects of serum from patients with rheumatoid arthritis upon the production of collagen and its properties of wound healing.

Dr. R. D. Harkness, of University College, London, is continuing his investigation into the tensile strength of collagen.

In the Department of Physiology at the University of St. Andrew's, Dr. F. Steven is studying the protein structure of various types of tissue obtained from joints affected by rheumatoid arthritis and other rheumatic diseases, and comparing these with normal joint substances.

Dr. P. J. Lachmann, at the Department of Pathology, University of Cambridge, has been investigating immunoconglutinin, which has been found to be altered in rheumatic disease, particularly rheumatoid arthritis.

Dr. J. S. Percy, at the Royal Victoria Infirmary, Newcastle-upon-Tyne, is studying the levels of immunoconglutinin previously reported to be raised in rheumatoid arthritis.

Dr. P. G. Walker, at the Institute of Orthopaedics, Stanmore, has been investigating certain chemical substances contained in collagen by chromotography.

Dr. T. Bitter, at St. Mary's Hospital, Paddington, associated with Dr. Helen Muir, has been investigating chemical properties of amyloid tissue.

Mr. R. Ewins, also at St. Mary's Hospital, working under Prof. W. S. Peart, has studied the pattern of certain chemicals contained in the urine of patients with rare bone diseases, often the result of genetic abnormalities.

Dr. P. W. Kent, in Prof. Sir Hans Krebs' Department of Biochemistry at the University of Oxford, has received a grant to investigate the chemical linkages in cartilage.
(2) Rheumatoid Factor.-The abnormal protein called the "rheumatoid factor" found in the blood of a high percentage of patients with rheumatoid arthritis and in some of their relatives, is being studied by $\mathrm{Dr}$. K. Walton in the Department of Experimental Pathology in the University of Birmingham under Prof. J. R. Squire.

In the same department it has been found possible to study cells from the synovial lining joints, and suspensions of these cells have been grown in the presence of both normal and rheumatoid sera.

At the Oxford Regional Rheumatism Research Centre, Dr. J. N. McCormick is studying the distribution of rheumatoid factor in the tissues, and Dr. G. Arapakis is studying the behaviour of rheumatoid factor under differing conditions by means of special apparatus such as the ultracentrifuge.

Evidence that the lymphoid cells in patients with rheumatoid arthritis may differ from normal cells is being investigated by Dr. I. Leslie in the Department of Biochemistry at Queen's University, Belfast.

(3) Immunology.-Dr. R. D. Wigley of Palmerston North Hospital, New Zealand, has found that certain strains of mice which are bred locally develop a disease with many features of disseminated lupus erythematosus.

Dr. D. G. Scott, in the Department of Dermatology at the University of Leeds, has developed special methods of staining affected tissues.

(4) Physiology and Metabolism of Corticosteroids.Prof. I. E. Bush and his fellow workers in the Department of Physiology, at the Medical School, Birmingham, have found that two particular enzymes are concerned with the breakdown of corticosteroids.

At the Kennedy Institute of Rheumatology, West London Hospital, research continues under Dr. O. Savage on the clinical aspects of corticosteroid treatment.

Dr. John Paul, of the Institute of Biochemistry at Glasgow University, has been studying the rate of entry of drugs into specially-prepared cells.

At the Rheumatism Research Centre in Sheffield, Dr. H. F. West is investigating the metabolism of corticosteroids by gas chromatography.

Dr. D. L. Gardner, in the Department of Pathology at the University of Edinburgh, is studying the integration of the activity of the adrenal cortex with other organs, particularly the heart.

(5) Synovial Tissue.-Dr. J. R. E. Fraser, in the Department of Medicine at the University of Melbourne, has established a method of growing synovial cells artificially.

(6) Genetics.-Dr. E. Kaklamanis, working under Prof. E. G. L. Bywaters at the Canadian Red Cross Memorial Hospital at Taplow, has been using new methods of genetic survey in studying the saliva and blood of patients with rheumatic fever compared with a control group. 
Dr. A. Kay, together with Dr. F. Bach and Mrs. P. Coates, in the Chelsea and Kensington Rheumatism Units, is studying fertility in women with rheumatoid arthritis.

(7) Polymyalgia Rheumatica.-Dr. F. M. Andrews, at the Rheumatism Research Department of the Oxford Region at Stoke Mandeville, is making a follow-up study of patients who were first seen 4 years ago.

(8) The Skin.-The association between psoriasis and rheumatoid arthritis is being investigated by Dr. $H$. Baker in the Skin Department of the London Hospital.

(9) Research in Africa.-Financial help is being given to Dr. C. O. Alele, of the Department of Medicine at the University of Lagos Medical School, Nigeria, to carry out a study of polyarthritis in that country. Dr. Alele has been under training in the Rheumatism Department at Manchester University and will receive advice from Manchester in Nigerian studies.

(10) Gout.-At King's College Hospital Medical School, Dr. K. A. Barlow has been investigating renal function, and Dr. A. C. Pollard, in the Department of Chemical Pathology, Charing Cross Hospital Medical School, is studying uric acid metabolism in patients with gout.

(11) Osteo-arthritis.-Prof. D. H. Collins, in the Department of Pathology at the University of Sheffield, has bent the technical resources of his department towards research into the pathology of bone and joint diseases. In this he has been assisted by Dr. G. Meachim and Dr. M. H. Young.

Dr. John Glyn, at the Prince of Wales Hospital, Tottenham, with the cooperation of the Institute of Orthopaedics, has been investigating the observation that patients who have suffered from poliomyelitis often do not develop osteo-arthritis in the limbs which have become paralysed.

(12) Orthopaedic Surgery.--Since the beginning of 1961 a co-operative study of the place of orthopaedic surgery in the treatment of patients with rheumatic disease has been carried out in the Rheumatism Unit in Edinburgh under the supervision of Dr. J. J. R. Duthie and Mr. Douglas Savill. At the moment Mr. Savill is visiting Professor of Orthopaedic Surgery in California and Mr. R. N. Tinning has continued the work assisted by $\mathbf{M r}$. J. K. Browne. The patients are seen at a combined medical/orthopaedic clinic so that the opinions of the rheumatologist and the surgeon can be co-ordinated.

Another combined medical/orthopaedic rheumatic clinic has been started at the Chelsea and Kensington Rheumatism Unit under Dr. A. St.J. Dixon and Mr. A. Kates. In addition, Dr. A. Kay, in this unit, is carrying out research to find out how hand deformities occur in rheumatoid arthritis.
(13) Study of Twins with Rheumatoid Arthritis.-To investigate environmental and inherited factors in the aetiology of rheumatic diseases, with the co-operation of centres in Great Britain and abroad, 229 pairs of twins with rheumatoid arthritis have now been found. The study will continue until March, 1964, and the twins will then be seen by the Council's Field Survey Unit.

\section{Equipment}

For Prof. Hartfall in the University of Leeds, an oscilloscope has been purchased to allow Dr. V. Wright to carry out an investigation of joint stiffness and the study of the rheological properties of skin.

In Guy's Hospital Medical School, London, Prof. W. J. H. Butterfield is using a galvonometer to study the blood flow through the fingers of rheumatic patients, especially those with scleroderma.

In the Department of Biochemistry and Chemistry at St. Bartholomew's Hospital, Dr. D. M. G. Armstrong has been provided with equipment for studies of collagen.

In addition, special equipment is in use at the Royal Free Hospital by Dr. A. T. Richardson, at the Royal National Hospital for Rheumatic Diseases, Bath, by Dr. G. D. Kersley, and at University College, Cardiff, by Professor J. Pryde.

\section{Geigy Travelling Fellowships}

Mr Alexander Kates, F.R.C.S.-For visits to centres in Sweden, Finland and Switzerland.

Miss I. M. Bett, B.Sc.-For visits to centres in the United States.

Prof. W. G. Spector, M.B., Ch.B.-For visits to centres in Australia and the United States.

Dr. J. S. Beck, M.R.C.P.-To attend the American Rheumatism Association meeting in the United States.

Dr. G. W. G. Sharp's account of his work at Harvard from 1962-63 is included in the Annual Report, p. 87.

\section{Geigy Commonwealth Fellowships}

Dr. W. A. C. Douglas, M.R.A.C.P. (Australia) at the Postgraduate Medical School, London.

Dr. D. G. Palmer, M.D., M.R.A.C.P. (New Zealand) at Birmingham University.

Dr. J. R. Topp, M.D. (Canada) at the Canadian Red Cross Memorial Hospital, Taplow.

\section{Chairs of Rheumatology}

These are held by Prof. E. G. L. Bywaters, F.R.C.P., at the Postgraduate Medical School of London, and by Prof. J. H. Kellgren, F.R.C.P., F.R.C.S., at the University of Manchester.

Full reports of the activities of their departments are contained in the Annual Report, pp. 25-27. 


\section{EDUCATION}

Symposia were held in 1963 on "Inflammation and the role of fibrin in the rheumatic diseases" and "Cytological aspects of joint tissues".

The Council issues "Reports on Rheumatic Diseases" three times a year to all general practitioners in the National Health Service in order to help keep them up-to-date with the results of research and new methods of treatment.

The Heberden Society, which is affiliated to and supported by the Council, holds regular clinical and scientific meetings which are attended by physicians, surgeons, and scientific workers from all parts of the country and from overseas.

The Council encourages research workers to publish their results in the Annals of the Rheumatic Diseases.

\section{COMMONWEALTH}

A full report of the work of the autonomous affiliated Associations in Canada, Australia, and New Zealand is included in the Annual Report, pp. 39-43.

\section{NEW YORK RHEUMATISM ASSOCIATION}

Officers, 1964-65

At the Annual Meeting of the New York Rheumatism Association held on March 24, 1964, at the New York Academy of Medicine, the following officers were elected: 